\title{
Companies in the Strasbourg Courtroom
}

\author{
Dean Spielmann ${ }^{*}$
}

\begin{abstract}
The following article was first presented as an address at the 5th Annual Conference of the Cambridge Journal of International and Comparative Law on 9 April 2016. It concerns themes developed in an earlier study and in a speech delivered in Strasbourg on 28 March 2014 during a seminar concerning new mechanisms of accountability for corporate human rights violations. The article discusses the issues arising under the European Convention on Human Rights in respect of companies in their capacity as holders of rights under the Convention and potential violators of rights guaranteed under the Convention.
\end{abstract}

\section{Keywords}

European Court of Human Rights, European Convention on Human Rights, Companies as Victims of Human Rights Violations, Corporate Accountability for Human Rights Violations

\section{Introduction}

It is always a great pleasure for me to come to Cambridge. The bonds between this alumnus and his alma mater are very strong, and so I want to express my thanks to the organising team of the $5^{\text {th }}$ Annual Conference for inviting me to deliver this keynote speech.

This year's annual conference focuses on the changing nature of the landscape of public and private power. In particular, the conference seeks to explore what new controls are necessary or desirable for existing or emerging areas of public and private power. Is the traditional public-private divide still accurate? Can public and private power be subjected to identical, equivalent or similar controls? Should legal

* LL.M. (Cantab). Former President of the European Court of Human Rights (2012-15). Since 13 April 2016, Judge of the General Court of the European Union. Honorary Fellow of Fitzwilliam College, Cambridge. Honorary Professor, University College London. Honorary Bencher of Gray's Inn. The author wishes to thank John Darcy, Deputy Head of the President's Private Office (ECtHR) and James Brannan of the English Language Division (ECtHR). 
entities enjoy the same rights as individuals? Should they be subjected to identical obligations? And if so, what is the role of the State?

In this presentation, and in my capacity as former President of the European Court of Human Rights, I would like to present the approaches adopted by the Strasbourg Court as to the status of legal entities under the European Convention on Human Rights. 'The title of my keynote speech is therefore: 'Companies in the Strasbourg Courtroom'. In the first part of my presentation, I shall try to give an answer to the question: Should companies be regarded as potential victims of human rights violations? In the second part of my speech, I shall endeavour to address the question: Should companies be held accountable for human rights violations?

\section{Should companies be regarded as potential victims of human rights violations?}

Is it normal for companies to enjoy human rights protection? Or to put it differently, do companies need human rights? The fact that they do actually enjoy humanor fundamental-rights protection today is not in dispute. In 1950, the elevation of the person-natural or legal-on the international scene was revolutionary. ${ }^{2}$ Indeed, as early as 1950, the weakness of the argument that only States were to be recognised as subjects of international law-reflecting the prevailing opinion in some quarters when the Convention was being drafted-has been pointed out. ${ }^{3}$ It has been rightly emphasised that introducing the right of individual petition was a major development. ${ }^{4}$ It was eloquently highlighted that 'the object of the Convention (...) is to protect the rights of the individual citizen-of the man on the Clapham omnibus.

1 Convention for the Protection of Human Rights and Fundamental Freedoms (adopted 4 November 1950, entered into force 3 September 1953) 213 UNTS 221 (hereafter 'Convention').

2 See Dean Spielmann, 'Should companies be regarded as potential victims of human rights violations?' (forthcoming).

3 AH Robertson, 'The European Convention for the Protection of Human Rights' (1950) 27 BYIL 145, 154.

4 ibid $154-55$.

5 ibid 154. 
However, the idea that the right of individual petition was not only enjoyed by the 'man on the Clapham omnibus', but also by companies, was not really discussed at the time that the right was first introduced. Indeed, the very legitimacy of regarding companies as potential victims of human rights violations has never been seriously questioned. Extensive case-law of the European Court of Human Rights concerning the protection of property, ${ }^{6}$ freedom of expression, ${ }^{7}$ respect for home and privacy (particularly in the context of search and seizures operated by State authorities) ${ }^{8}$ etc, shows that companies have successfully brought claims to Strasbourg and have thereby contributed to the development of the European Convention on Human Rights as a living instrument.

Nonetheless, it might seem odd at first sight to accept that companies can claim that human rights abuses have occurred to their detriment and that, as a consequence, they are entitled to compensation for pecuniary or even nonpecuniary damage. Are human rights not meant for human beings alone? Is it selfevident that companies are covered by the right to lodge an individual application? Is it not strange that the locus standi of companies has never been seriously disputed? The drafting history of the Convention shows that the text was always intended to include all corporate persons. It is interesting in this context to note that the United Kingdom delayed recognising the right of individual petition until such time as the Burmah Oil Company could no longer bring a case to Strasbourg in respect of an Act of Parliament depriving it of compensation for the destruction of property. ${ }^{9}$ It should also be noted that traditional diplomatic protection and the pacific settlement of disputes had developed in the Permanent Court of International December 1994); Sud Fondi Srl and Others v Italy App no 75909/01 (ECtHR, 20 January 2009); Centro Europa $7 \mathrm{Srl}$ and di Stefano v Italy App no 38433/09 (ECtHR, 7 June 2012); Conseil et Courtage SA and Christian de Clarens SA v France App no 70160/01 (ECtHR, 25 January 2007). Eg, Verlagsgruppe News GmbH v. Austria (no 1 and no 2) App nos 76918/01 and 10520/02 (ECtHR, 14 December 2006); Times Newspapers Ltd $v$ the United Kingdom (nos 1 \& 2) App nos 3002/03 and 23676/03 (ECtHR, 10 March 2009); Axel Springer AG v Germany App no 39954/08 (ECtHR, 7 February 2012); Financial Times Ltd and Others $v$ the United Kingdom App no 821/03 (ECtHR, 15 December 2009); Glas Nadezhda EOOD and Anatoliy Elenkov v. Bulgaria App no 14134/02 (ECtHR, 11 October 2007). Eg, Saint-Paul Luxembourg SA v Luxembourg App no 26419/10 (ECtHR, 18 July 2013); Wieser and Bicos Beteiligungen GmbH v Austria App no 74336/01 (ECtHR, 16 January 2008); Société Colas Est and Others v France App no 37971/97 (ECtHR, 16 July 2002).

9 Marius Emberland, The Human Rights of Companies: Exploring the Structure of ECHR Protection (OUP 2006) 29, relying inter alia on AWB Simpson, Human Rights and the End of Empire: Britain and the Genesis of the European Convention (OUP 2004) 1092-201. 
Justice, the most celebrated case being the Chorzow Factory case, ${ }^{10}$ which has been cited on many occasions by the European Court of Human Rights.

In Strasbourg, legal persons, including corporations and other forms of company, provided that they are not emanations of the State, and are in fact treated as 'non-governmental organisations' for the purposes of Article 34 of the Convention (right of individual petition). ${ }^{11}$ State-run corporations, if they are emanations of public authorities are, however, excluded. ${ }^{12}$ At the European Union level, the situation is different. A recent ruling in Bank Mellat $v$ Council (judgment of the General Court, ${ }^{13}$ recently confirmed by the Court of Justice), ${ }^{14}$ is interesting in this respect. In that case, the applicant was an Iranian bank which contested a Council Regulation imposing sanctions on it. The Council and the Commission claimed that the bank was an emanation of the Iranian State. The General Court dismissed this argument as follows:

Neither in the Charter of Fundamental Rights of the European Union nor in European Union primary law are there any provisions which state that legal persons who are emanations of the States are not entitled to the protection of fundamental rights. On the contrary, the provisions of the Charter that are relevant to the pleas raised by the applicant, and in particular Articles 17, 41 and 47, guarantee the rights of 'everyone', a wording which includes legal persons such as the applicant. ${ }^{15}$

Companies come to Strasbourg as emancipated actors. Shareholders are normally not entitled to step in as applicants. As the Court has said on numerous occasions, the piercing of the corporate veil or disregarding of a company's legal personality will be justified only in exceptional circumstances. These include where it is clearly established that it is impossible for the company to apply to the Convention institutions through the organs set up under its articles of incorporation or-in the event of liquidation-through its liquidators. ${ }^{16}$

11 M Kučera, 'Convergence and Conflicts between Investment Law and Human Rights Law: A Dispute Settlement Approach-Jurisdiction ratione personae' in W Ben Hamida and F Coulée (dir.), Convergences and Contradictions between Investment Law and Human Rights Law, A Litigation Approach (Proceedings of the Journée d'études de l'Institut International des Droits de l'Homme, Paris, 27 November 2015) (Pedone 2017) 41-64.

12 For many examples, see ibid.

13 Case T-496/10 Bank Mellat v Council ECLI:EU:T:2013:39.

14 Case C-176/13 P Council v Bank Mellat ECLI:EU:C:2016:96.

15 Bank Mellat $v$ Council (n 13) para 36.

16 Agrotexim and Others v Greece (1995) Series A no 330-A. See also Kučera (n 11). 
But what about the enjoyment of human (or should I say, fundamental) rights? Are companies entitled to benefit from the full range of Convention rights? Applications lodged by companies have contributed to the development of the case law of the European Court of Human Rights. Admittedly, some provisions, such as article 2 (the right to life), article 3 (the prohibition against torture or inhuman and degrading treatment and punishment) and perhaps also article 9 (freedom of thought, conscience and religion), as well as article 12 (the right to marry), cannot be invoked by companies to their benefit. In particular, the wording of article 12 applies to 'men' and 'women' and even a more dynamic interpretation of this provision, extending it to 'mergers' and 'acquisitions' of companies, would amount to an absurd result. However, two provisions explicitly apply to companies. Article 1 of Protocol No 1 to the Convention applies equally to 'natural persons' and 'legal persons', and article 10(1), third sentence, of the Convention refers to media 'enterprises'. Moreover, article 1 of the Convention provides that ' $[t]$ he High Contracting Parties shall secure to everyone within their jurisdiction the rights and freedoms defined in Section I of [the] Convention. Many provisions explicitly state that they are for the benefit of 'everyone'.

Article 10 of the Convention has often been invoked by companies: Sunday Times is probably the first and most prominent example. ${ }^{17}$ Other Convention provisions that are frequently applied by the Strasbourg Court in cases concerning companies are, not only article 1 of Protocol No 1, but also article 6 (right to a fair hearing), article 8 (right to respect for private life), article 4 of Protocol No 7 (double jeopardy or ne bis in idem) and more recently, article 7 (no punishment without law).

Companies have provided the Court with the possibility of developing its case law. Suffice it to mention the developments bringing commercial speech within the ambit of article 10 of the Convention (Markt Intern and Klaus Beerman $v$ Germany $)^{18}$ and the admission that business premises are considered to be a company's 'home' within the meaning of article 8 of the Convention (Société Colas Est and Others $v$ France). ${ }^{19}$ Turning to the protection of property, the relevant provision (article 1 of Protocol No 1) explicitly states that 'every natural or legal person is entitled to the peaceful enjoyment of his possessions'. Intellectual property cases often involve corporations. The Court held in Anheuser-Bush v Portugal that 
intellectual property fell under the protection of article 1 of Protocol No $1 .^{20}$ Since a 'legitimate expectation' of obtaining an asset will itself be protected under that Article in certain circumstances, it was held in Centro Europa $7 v$ Italy that, by granting the applicant company a television broadcasting licence without allocating it any broadcasting frequency, Italy was in breach of this provision. ${ }^{21}$ Other cases concern tax-related issues. In the case of Yukos, ${ }^{22}$ a case concerning inter alia tax assessment proceedings, the Court found that the assessment of the penalties in respect of the year 2000 and the doubling of the penalties for 2001 were unlawful and in breach of article 1 of Protocol No 1. In the enforcement proceedings against the applicant company, the domestic authorities had failed to strike a fair balance between the legitimate aim of these proceedings and the measures employed, in breach of the same Convention provision. The Court further held that, in the 2000 tax assessment proceedings, the applicant company had not had sufficient time for preparation of the case at first instance and on appeal, in breach of article 6 of the Convention.

In its judgment on the application of article 41, the Court decided that the finding of a violation constituted in itself just satisfaction for the non-pecuniary damage sustained by the applicant company. It held, however, that the respondent State was to pay the applicant company's shareholders, as they stood at the time of the company's liquidation; and, as the case may be, their legal successors and heirs, the sum of EUR 1,866,104,634 in respect of pecuniary damage. It also decided that the respondent State was to pay EUR 300,000 in costs and expenses, which sum was to be paid to the Yukos International Foundation, at the request of the applicant company.

However, non-pecuniary damage is not necessarily excluded in cases concerning companies. Indeed, a major development in the Court's case-law has consisted precisely in awarding sums in respect of such damages to companies. In Comingersoll SA $v$ Portugal ${ }^{23}$ the applicant was a company involved in enforcement proceedings. This was not a particularly complicated case, involving mainly a 'length of proceedings' issue. After several years the applicant had complained of the length of the civil proceedings in question. The Court found a breach of article 6 of the Convention. The Court also held, however, that a company had a right 
under article 41 to compensation for non-pecuniary damage sustained as a result of a violation of article 6 of the Convention. This is probably the most significant development. Awarding moral damages to a company under the European Convention of Human Rights might be perceived as rather artificial, although domestic courts have in the past awarded such damages.

To conclude the first part of my intervention: the crux of human rights at its inception was to 'protect the weak' - human beings - from the abuses of the strong and powerful-the state. It is certainly true that the underlying value of individual dignity in the Convention system can hardly be mobilised to justify the openness with which companies have been received in Strasbourg. In a globalised world, distinguishing between individuals and companies, granting fundamental rights to the former but not to the latter would have led to insurmountable practical difficulties. It is my submission that accepting companies in the Strasbourg courtroom is essential for upholding the rule of law, as many cases eloquently demonstrate.

This brings me to my second query.

\section{Should companies be held accountable for human rights violations?}

It is, by this stage, clearly established that the Convention has very real implications for private parties - including corporations-who interfere with the human rights of others. Companies may violate human rights by employing child labourers; discriminating against certain groups of employees (such as union members and women); attempting to repress independent trade unions and discouraging the right to bargain collectively; failing to provide safe and healthy working conditions; and limiting the broad dissemination of appropriate technology and intellectual property. Companies also dump toxic wastes, and their production processes may have consequences for the lives and livelihoods of those people in neighbouring communities. $^{24}$ Many attempts have been made at the level of the United Nations 
to hold companies and transnational corporations to account by drawing up codes and guidelines. ${ }^{25}$

In an article that I contributed to a study entitled Human Rights and the Private Sphere, I wrote (and this was in 2007) that the horizontal effect of Convention rights-Drittwirkung-had been extended by the Court, but had not as yet been fully conceptualised. ${ }^{26}$ Since then, the number of such cases has increased significantly, and this in relation to many Convention rights. But the legal or theoretical basis for the indirect horizontal effect of Convention rights remains the same.

To begin with, it derives from the text of the Convention itself. We need not dwell on the obvious point that the Convention binds only the Contracting States as a matter of classic treaty law, so that no other party or person can be called to account before the European Court of Human Rights. That is determinative of the admissibility of any application, of course, but our interest today is in the substance of human rights. It is article 1 that provides the textual 'hook' upon which to hang indirect horizontal effect-States 'shall secure to everyone within their jurisdiction' the rights set forth in the Convention. This provision grounds the doctrine of positive obligations, which makes the link between the acts of private parties, including corporate entities, and State responsibility under the Convention.

I would mention also article 13. Although the Court appears not to have had the occasion to explore this particular point, on a straightforward reading of this provision, it requires the State to ensure that for every violation of human rights there is an effective remedy. I do not read the last part of the provision'notwithstanding that the violation has been committed by persons acting in an official capacity'-as limiting its scope so as to exclude the acts or omissions of private parties. As the Court has said, article 13 requires the provision of a domestic

25 See UN Human Rights Council, United Nations Guiding Principles on Business and Human Rights (OHCHR 2011), UN Doc HR/PUB/11/04; UN Human Rights Council, The Corporate Responsibility to Protect Human Rights: An Interpretive Guide (OHCHR 2012), UN Doc HR.PUB.12.2; UN Human Rights Council, Protect, Respect and Remedy: A Framework for Business and Human Rights: Report of the Special Representative of the Secretary General on the Issue of Human Rights and Transnational Corporations and Other Business Enterprises (OHCHR 2008), UN Doc A/HRC/8/5; United Nations, 'The Ten Principles of the United Nations Global Compact' <https://www.unglobalcompact.org/what-is-gc/mission/principles> (accessed 6 August 2016).

26 Dean Spielmann, 'The European Convention on Human Rights' in Dawn Oliver and Jörg Fedtke (eds), Human Rights in the Private Sphere: A Comparative Study (Routledge-Cavendish 2007) 427-64. 
remedy to deal with the substance of an 'arguable complaint' under the Convention and to grant appropriate relief.

Also relevant here is the cardinal principle of interpretation that protection of Convention rights must be practical, concrete and effective, and not illusory or theoretical. It is not the only principle of interpretation that bears on the issue. The 'living instrument' doctrine also informs the Court's approach, and leads it to have regard to standards developing at both national and international levels. In this way, new legal tendencies can inform the meaning of the Convention.

In the same general sense, I would also refer to the important dictum in the Selmouni case, where the Court said that:

It takes the view that the increasingly high standard being required in the area of the protection of human rights and fundamental liberties correspondingly and inevitably requires greater firmness in assessing breaches of the fundamental values of democratic societies. ${ }^{27}$

It is a potent statement of the Court's determination to ensure the continuing effectiveness of the Convention in safeguarding human rights.

The Court's case law contains many cases which have, as their origin, the acts or omissions of a private party, or in any event a non-State entity. Such cases have arisen under many different provisions of the Convention and the Protocols. I have selected a small number of them for the purposes of our discussions today.

The first of these is the case Rantsev $v$ Cyprus and Russia, ${ }^{28}$ decided in 2010. I was part of the Chamber that decided the case, and I believe that it must be seen as a landmark judgment of this Court. It is particularly relevant to our theme today since the subject-matter was a very serious one-human trafficking. And the context was the well-known, indeed flagrant, sexual exploitation of young women from Eastern Europe in Cyprus. The perpetrators were commercial operators, the owners of night clubs and other establishments taking part in the sex trade. So we can regard it as a paradigm case on the subject of corporate accountability. The unfortunate victim, Ms Rantseva, was just 20 years old when she died, and that tragedy eventually brought the situation in Cyprus to the international scrutiny of the Court. In its reasoning, the Court placed article 4 in the same category as articles 2 and 3, these three provisions embodying the basic values of democratic society. It followed from this that there was a very strong positive obligation on the 
State. This included the duty-already established in the case Siliadin v France ${ }^{29}$ to have robust criminal law provisions and to apply them with all rigour.

The obligation also extended to taking measures to prevent and combat trafficking, and to protect its victims. Here the Court drew on the relevant, recent international instruments addressing the problem-the Palermo Protocol of the United Nations ${ }^{30}$ and the Anti-Trafficking Convention of the Council of Europe. $^{31}$ The Court drew on the rigorous standards developed under articles 2 and 3 to require the authorities to take operational measures to protect victims and potential victims: if the authorities were aware, or ought to have been aware, of circumstances giving rise to a credible suspicion that an identified individual had been or was at real and immediate risk, then a failure to take appropriate measures of protection amounts to a violation of article 4 . In the same way as for article 2, there are some limits to this obligation-it does not place impossible or disproportionate burdens on the national authorities. But the assessment of what is proportionate is informed by the measures that are laid down in the relevant international treaties against trafficking.

The Court went further and derived a strong procedural obligation on the State to investigate potential trafficking situations, along the same lines as investigations into deaths and allegations of ill-treatment under article 3. It also addressed the transnational character of the phenomenon, requiring States to engage in international co-operation as necessary. This, I would observe, is a point of particular importance regarding the activities of corporations, which are frequently on a multinational or indeed global scale. On the facts before it the Court held that Cyprus had very clearly failed to put in place an adequate legal and administrative framework to combat sex trafficking, and had failed to take protective measures for Ms Rantseva. Russia was also found to have violated article 4 , by its failure to investigate what happened on its territory when the victim was recruited to go to Cyprus.

I consider that this case stands out as a very good illustration of the strong duty that the Convention places on States to adopt a robust and rigorous approach to the risk - and the reality — of violations perpetrated by private actors of the most

30 Protocol to Prevent, Suppress and Punish Trafficking in Persons, Especially Women and Children, Supplementing the United Nations Convention against Transnational Organized Crime (adopted 12 December 2000, entered into force 25 December 2003) (2001) 40 ILM 335.

31 Council of Europe Convention on Action Against Trafficking in Human Beings (adopted 3 May 2005, entered into force 1 February 2008) CETS 197. 
fundamental rights safeguarded by the Convention. I mention also Siliadin, ${ }^{32}$ which arose in the setting of what is called domestic slavery, and I would also mention the more recent case of C.N. $v$ United Kingdom. ${ }^{33}$ In both of those cases, the respondent State was found to have violated article 4 owing to the shortcomings in the domestic criminal law, which lacked the necessary specificity and rigour, with the effect that the perpetrators were not properly held to account for their actions. So we see that the criminal law, and the vigour with which it is applied to private parties, are important elements of the positive obligation that can arise in relation to articles 2, 3 and 4 .

In relation to other provisions of the Convention, the focus can be different, with more emphasis on civil or administrative aspects such as licensing, authorising, monitoring and inspection.

I take as my example a case, Vilnes and others $v$ Norway. ${ }^{34}$ Its interest for present purposes lies in its subject-matter, safeguarding the health and safety of workers in a high-risk profession-deep-sea diving. It, too, can be seen as a paradigm, as it concerns human rights, commercial interests and the role of the domestic authorities. The Court considered the case under articles 2 and 8 . Regarding article 2, it recalled the positive obligation to take all appropriate steps to safeguard life, which entails, above all, a primary duty on the State to put in place a legislative and administrative framework designed to provide effective deterrence against threats to the right to life. It said:

The Court considers that this obligation must be construed as applying in the context of any activity, whether public or not, in which the right to life may be at stake, and a fortiori in the case of industrial activities, which by their very nature are dangerous. In the particular context of dangerous activities special emphasis must be placed on regulations geared to the special features of the activity in question, particularly with regard to the level of the potential risk to human lives. They must govern the licensing, setting up, operation, security and supervision of the activity and must make it compulsory for all those concerned to take practical measures to ensure the effective protection of citizens whose lives might be endangered by the inherent risks. ${ }^{35}$

ibid. 
The facts of the case are rather complex-so I will not try to summarise them. It suffices to say that the Court found a problem with regard to just one point, namely the fact that 'decompression tables' used by companies (vital to ensuring the safety of divers) were not standardised at the time the applicants were working as divers. This meant that the different companies could set their own standards, and therefore could 'cut corners' with employee safety. There was also a degree of opacity about the tables that made it difficult for the applicants to evaluate the risks they faced; and this at a time when the long-term effects of their professional activities on their health were unknown.

On this issue, the analysis moves to article 8 , and it becomes a question of the right to respect for private life, and the corresponding positive obligations on the State. The Court recalled the relevant case law about the obligation to provide individuals with access to information about health risks, and-significantlyidentified a duty in certain circumstances to go further and to provide information. Here the authorities had fallen short. The labour inspectorate and the petroleum directorate had authorised diving operations without sight of the important decompression tables. The judgment states:

It seems that the diving companies were left with little accountability vis-à-vis the authorities, and were allowed to deal with the tables as their business secrets and thus enjoyed for a considerable period a wide latitude in opting for decompression tables that offered competitive advantages serving their own business interests. ${ }^{36}$

Corporate accountability - at the national level of course-is thus the real point in this case, approached via the positive obligations on the State. The Court concluded:

In the Court's view it would therefore have been reasonable for the authorities to take the precaution of ensuring that the companies observe full transparency about the diving tables used and that the applicants, and other divers like them, receive information on the differences between tables, as well as on their concerns for the divers' safety and health, which constituted essential information that they needed to be able to assess the risk to their health and to give informed consent to the risks involved. This the authorities could have done when, for example, granting authorisation of diving operations and upon inspections. Had they done so they might conceivably have helped to eliminate sooner the use of rapid tables as a means for companies to promote their own commercial interests, potentially adding to the risks to divers' health and safety. ${ }^{37}$ 
The Vilnes judgment draws on some of the Court's key rulings on environmental issues - that is a very important body of case law that is also highly relevant to our theme today. I refer to cases such as Guerra $v$ Italy, ${ }^{38}$ López Ostra $v$ Spain, ${ }^{39}$ Budayeva v Russia, ${ }^{40}$ Kolyadenko v Russia ${ }^{41}$ and Muñoz Díazv Spain. ${ }^{42}$ That is not an exhaustive list by any means. One would add the cases Tătar $v$ Romania, ${ }^{43}$ Fadayeva $v$ Russia ${ }^{44}$ and Grimkovskaya $v$ Ukraine ${ }^{45}$ (to name just three).

Very briefly, what emerges from this case law is the procedural dimension of article 8 when there are risks to lives and homes from industrial activity or manmade hazards. This includes the obligation to evaluate the risks beforehand, and to do so in an open, accessible way so that the persons who stand to be affected can be fully informed of the risks and can participate in the decision-making process. The right to challenge the decisions taken by the authorities effectively before an independent body should be available. These requirements were derived by the Court in the light of the Aarhus Convention, ${ }^{46}$ cited in many cases. Ongoing monitoring and inspection is also required. All of these elements go to the need for accountability in the environmental field so that article 8 rights are effectively protected.

Let me add that, just as the scope for corporate interferences with Convention rights is broad, so may a corresponding positive obligation arise on the State to ensure effective exercise of, and protection for, human rights.

Under article 9, for example, the Court found a violation of the State's positive obligation in the Eweida case, when the first applicant was forbidden to wear a cross at work. ${ }^{47}$ Or the issue may well present as a negative obligation, ie, an interference 
that calls for justification. See, for example, the case of Heinisch $v$ Germany, ${ }^{48}$ concerning the dismissal of a whistle-blower by a company running homes for the elderly. As you know, the difference between positive and negative obligations is not especially significant, since the relevant considerations are similar.

Finally, although there is not enough time to develop the point, let me simply note that the Convention can help to secure corporate accountability through the exercise of article 10 rights. It affords a high level of protection to those who play a watchdog function-above all the press and non-governmental organisations -and to speech that concerns matters of public concern. As the case law has established, the Convention affords protection to journalistic sources, and also ensures a right to receive information. These are valuable safeguards in holding up to public scrutiny possible violations of human rights, at home or abroad, by corporate entities.

\section{To conclude}

The potential development of respect for the fundamental rights of companies should go hand in hand with 'corporate accountability'. Positive obligations of the State authorities, calling for regulation of corporate activities, as well as increased awareness of the need to provide for essential counterbalancing factors, should play a role in this connection. Robust safeguards in holding up to public scrutiny possible violations of human rights, at home and abroad, by corporate entities are as necessary as the inclusion of companies amongst the beneficiaries of human rights protection. 